\title{
Influence of Cross Wind on Derailment of Railway Vehicle Running on Curved Track at Low Speed
}

\author{
Takahiro HOSOI and Katsuya TANIFUJI ${ }^{* 2}$ \\ $*^{2}$ Graduate School of Science and Technology, Niigata University, \\ 8050 Ikarashi 2-no-cho, Nishi-ku, Niigata-shi, Niigata, 950-2181 Japan
}

\begin{abstract}
Due to the lightening of railway vehicles and the improvement of operation speeds, the reduction of running safety by cross winds is becoming an important problem. In particular, the running safety tends to reduce when the vehicles are running on curved sections. When a cross wind acts on the vehicle running on a curve from the outer side, a flange climbing phenomenon can occur. In this study, a full vehicle model was constructed using a multi-body software, SIMPACK, and the running simulation on a curve was carried out to examine the running safety under the condition that a cross wind acted on the vehicle from the outer side of the curve. As a result, it is verified that the derailment coefficient of the first wheelset becomes large in the exit transition curve and that of the third wheelset does in the entrance transition curve and this trend is pronounced by larger wind forces. Here, the derailment coefficients at the timing the derailment occurs are different between the first and third wheelsets, and those derailment coefficients are much larger than the critical derailment coefficients obtained by Nadal's formula. Then an equivalent friction coefficient which depends on an attack angle is introduced in Nadal's formula. Consequently, the critical derailment coefficient considering the equivalent friction coefficient came close to the actual derailment coefficient.
\end{abstract}

Key Words : Railway, Simulation, Derailment, Cross Wind, Multi-Body Software

\section{1. 緒}

鉄道車両の軽量化と走行速度の向上により，横風による車両の走行安全性の低下が懸念される．特に曲線走行 中では，遠心力とカントの兼㸚合いにより，その走行安全性は横風によっても大きな影響を受ける．横風によっ て引き起こされる転覆に関する解析は，1972 年に国枝が提案した静的解析式(1)（いわゆる国枝の式）をはじめ, いくつかの研究が行われてきたが(2)(4)，横風による脱線を扱ったものは少ない.

最近では, 2005 年に JR 羽越本線で強風が原因と推定される脱線転覆事故が発生している(5).このような事故 を未然に防ぐため, 強風時にはその風速の大きさに応じた運転規制により,その走行速度の制限が行われている. その一方で，このような運転規制下では，曲線通過時には基本速度以下での走行となるため，横風による脱線を 助長することがある(6). その脱線は外軌側からの横風によるものであり，転覆よりも小さな風速で発生する．乙 かし, 文献(6)では脱線現象については十分な考察がされていない. その脱線現象はまだ不明確な部分が多いため, 横風が車両の脱線に及ぼす影響について検討することが望まれる.

そこで, 本研究ではマルチボディソフト SIMPACK(7)を用いて 1 車両モデルを構築し, 曲線走行中の車両に外軌 側から横風を作用させ，走行シミュレーションを行う。その結果得られる脱線係数などの各パラメータにより脱 線に至る車両の挙動の解析を行い，アニメーションでその様子を確認した．また，アタック角の影響を考慮した 等価摩擦係数(8)を用いて脱線係数と Nadal の限界脱線係数(9)を求め, 脱線係数と脱線挙動の対応関係を明らかにし た.

*原稿受付 2010 年 6 月 21 日

${ }^{* 1}$ 学生員, 新潟大学大学院 自然科学研究科（广950-2181 新潟県新潟市西区五十嵐 2 の町 8050)

*2 正員, フェロー, 新潟大学大学院 自然科学研究科

E-mail: tanifuji@eng.niigata-u.ac.jp 


\section{記 号の説明}

本報で用いる主な記号を以下に示す。

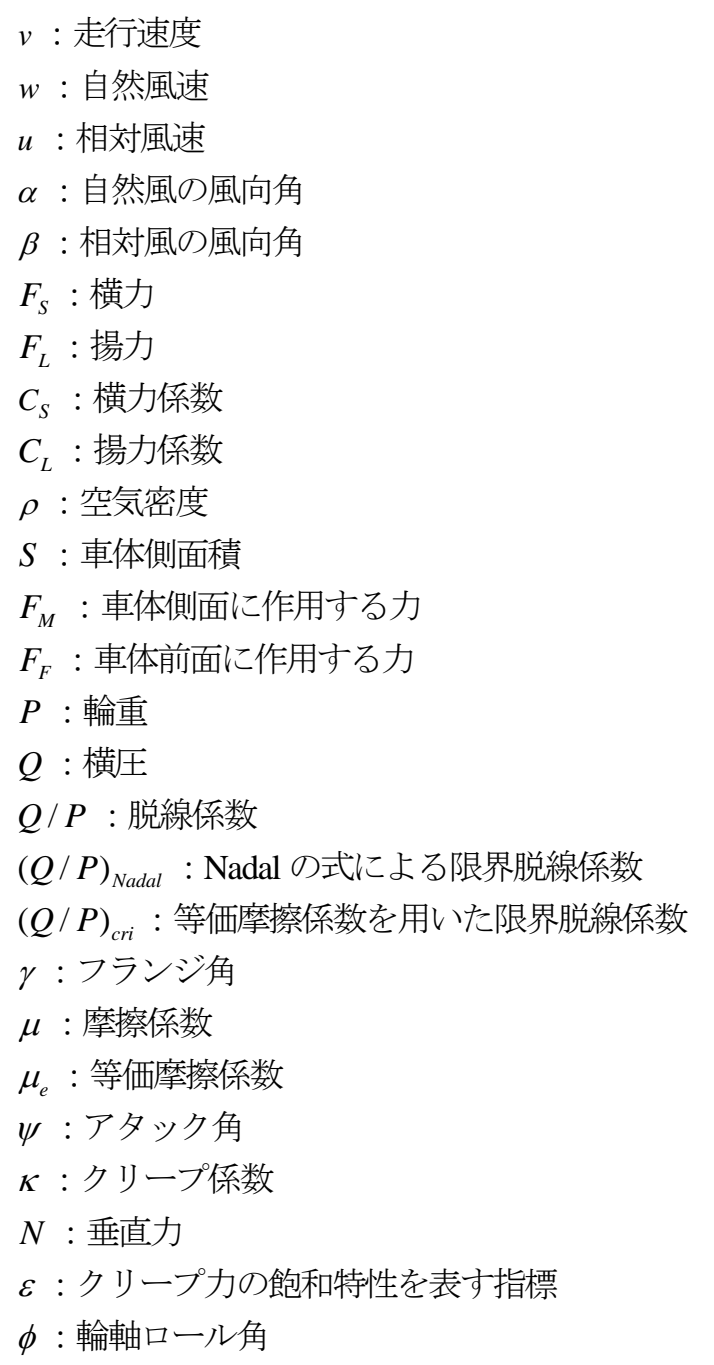

\section{2. 車両モデル}

本研究では鉄道車両の走行挙動を数值シミュレーションにより検討寸る. そこで, 実態に即したシミュレーシ ヨンが可能なマルチボディソフト SIMPACK ${ }^{(7)}$ を使用し，図 1 および図 2 に示す 1 車両モデルを構築した. この 車両モデルはボルスタレス台車を使用する 2 軸ボギ一車を想定している，自由度は車体，台車及び車輪軸でそれ ぞれ, 前後 $x$, 左右 $y$, 上下 $z$, ロール $\phi$, ピッチ $\theta, \exists ー \psi$ 方向の 6 自由度を有し, 1 車両で合計 42 自由度 である．また本モデルでは，車両が転覆する場合も考慮し，台車に対する車体の過度の変位を抑制するために， 車体・台車間の左右動ストッパ，上下動ストッパを考慮している（詳細は 4.1 節参照）．図 3 はその構造を模式 的に示したものである，ストッパには遊間が存在するが，車体・台車間の相対変位がある一定值を超えるとスト ッパ反力が生じ，その変位が抑制される．左右動ストッパは前・後各台車中央に一つずつ計 2 箇所，上下動ス卜 ッパは各台車左右に一つずつ計 4 箇所設置する. 


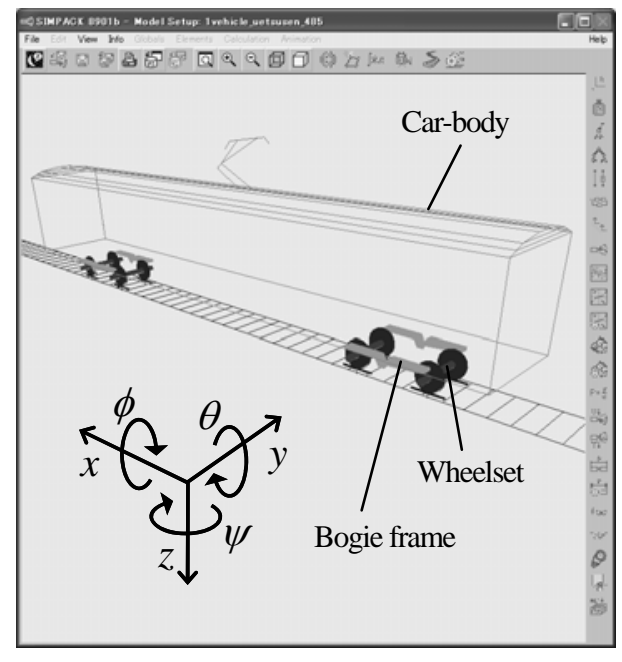

Fig. 1 Construction of full vehicle model

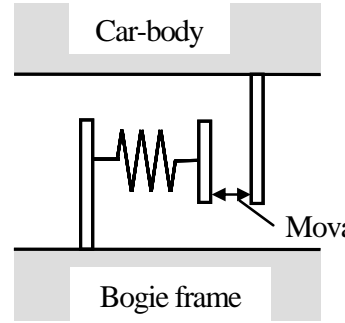

(a) For lateral motion

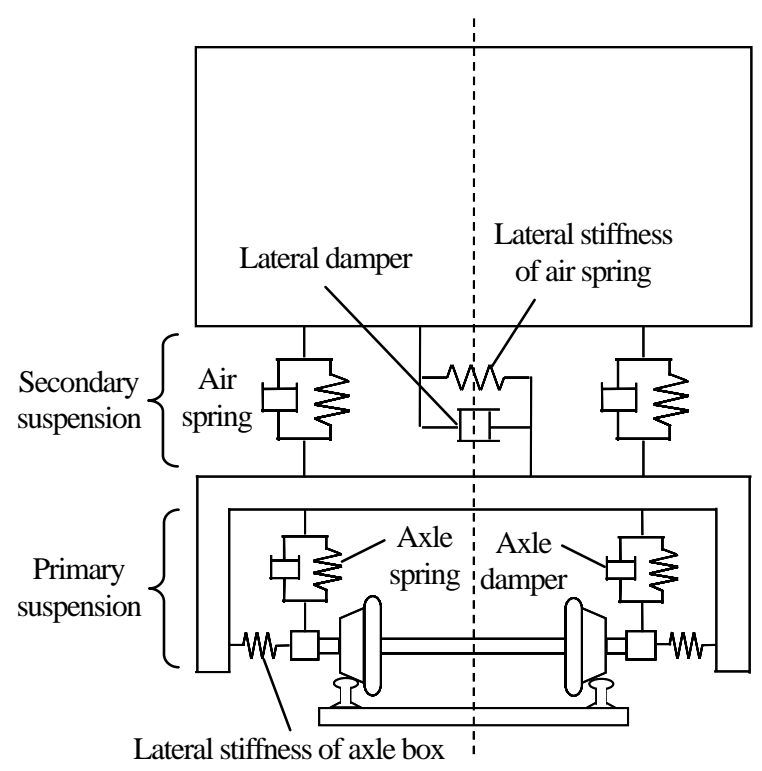

Fig. 2 Suspension model

Fig. 3 Mechanism of stopper

\section{3. 空気力のモデル化}

\section{$3 \cdot 1$ 車両が受ける風と空気力 ${ }^{(3)}$}

走行速度 $v$ の車両に風速 $w$, 風向角 $\alpha$ の自然風が吹きつけるとき, 車両には, 相対風速 $u$, 相対風の風向角 $\beta$ の相対風が作用する（付図参照）。その速度ベクトルの関係からu， $\beta$ はそれぞれ式(1)，(2)で表される.

$$
\begin{aligned}
& u=\sqrt{w^{2}+v^{2}+2 w v \cos \alpha} \\
& \beta=\cos ^{-1}((w \cos \alpha+v) / u)
\end{aligned}
$$

また一般に空気力は横力 $F_{S}$ および揚力 $F_{L}$ で式(3), (4)のように示される.

$$
\begin{aligned}
& F_{S}=\frac{1}{2} \rho u^{2} S C_{S} \\
& F_{L}=\frac{1}{2} \rho u^{2} S C_{L}
\end{aligned}
$$




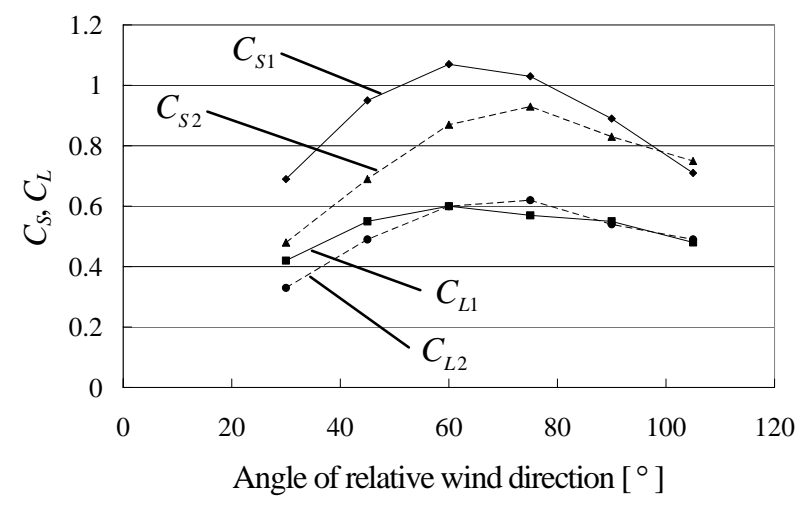

Fig. 4 Aerodynamic force coefficients quoted from Ref. 10

ここで， $\rho$ は空気密度， $S$ は車体側面積， $C_{S}$ および $C_{L}$ はそれぞれ横力係数，揚力係数である． $C_{S}, C_{L}$ は相 対風の風向角 $\beta$ に依存して変化する. 一様流による風洞実験によって得られる空気力係数は文献(10)を引用し, 図 4 に示すものを用いる. 図 4 のグラフは連結した列車を想定したものであり, 図中の $C_{S}, C_{L}$ に付けられた添 え字の 1 は先頭車両，2は中間車両を表している.

\section{$3 \cdot 2$ 先頭車両と後続車両に作用する空気力}

先頭車両では横風が車体側面部だけでなく車体前面部にも吹き付けることを考え, 式(3)で表される横力 $F_{S} を$ 図 5 のように車体側面に作用する力 $F_{M}$ と車体前面に作用する力 $F_{F}$ に分けて作用させる. 2 車両の列車を仮定す ると， $F_{M}$ は先頭車両，後続車両ともに同じ大きさの力が作用し， $F_{F}$ は先頭車両にのみ作用するものとする. $F_{M}$, $F_{F}$ はそれぞれ風圧中心高さの一点に， $F_{L}$ は車体底面中心部の一点に作用寸る．そのため両車両に作用寸る $F_{S} の$ 差が $F_{F}$ に相当するとし， $F_{F}$ と $F_{M}$ の関係は図 4 の值を参照して式(5)で与えられる.

$$
F_{F}=\frac{C_{S 1}-C_{S 2}}{C_{S 2}} F_{M}=0.23 F_{M}
$$

ここでは $C_{S 1}$ が最大となる相対風の風向角 $\beta=60^{\circ}$ の值を用いると, $C_{S 1}$ と $C_{S 2}$ の值はそれぞれ $1.07,0.87$ である. $F_{L}$ と $F_{M}$ の関係は，式(3)，(4)および(5)より求められ，以下のようになる.

$$
F_{L}=\frac{C_{L 1}}{C_{S 2}} F_{M}=0.69 F_{M}
$$

ここで, 揚力係数 $C_{L 1}$ は 0.60 である.

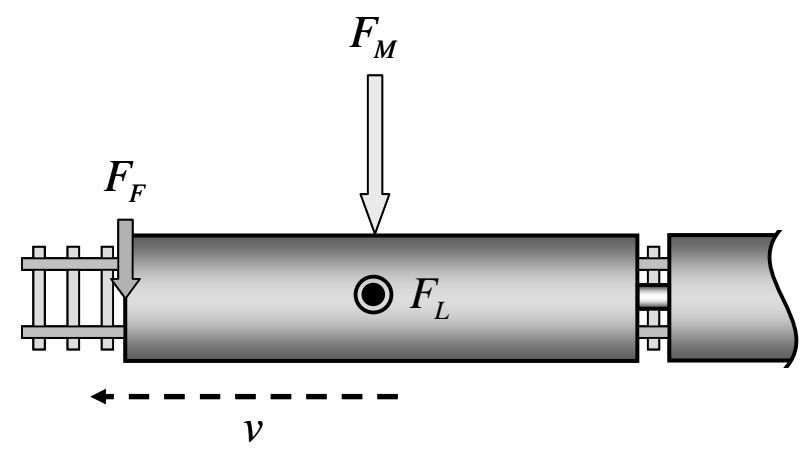

Fig. 5 Aerodynamic forces acting on leading car 


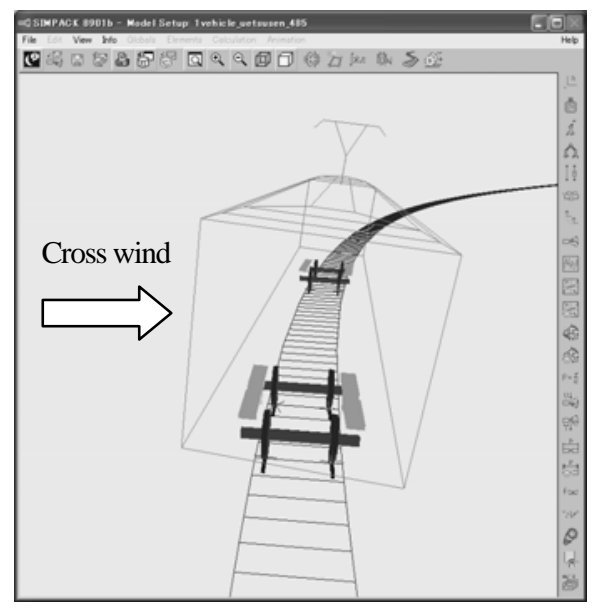

Fig. 6 Full vehicle model in SIMPACK

\section{4. シミュレーション}

\section{$4 \cdot 1$ 計算条件}

先頭車両を想定した 1 車両モデルを用い，シミュレーションを行う．図6ははそのシミュレーションの様子を示 したものである．車両諸元は在来特急電車相当のものを使用しており（付録参照），車輪踏面形状は在来線円弧 踏面，レール頭頂面形状は $50 \mathrm{kgN}$ 型レールである．車体・台車間に設置された左右動ストッパ，上下動ストッパ による反力はそれぞれ遊間を考慮し，図７のように設定する。ここでは，外軌側輪重の減少による乗り上がり脱 線を想定し，図6のように曲線走行中の車両に外軌側から横風を模擬した外力を作用させる. 特に基本速度以下 の走行では, 横風の影響に加え，カント超過により外軌側輪重の減少がより顕著になり，外軌側への乗り上がり が助長されると考えられる．衝撃的な作用を避けるため，図８のようにそれぞれの空気力は 0 からランプ状に増 加していき 20 秒以降一定值となる形状を用いる. なお, シミュレーションごとに空気力の大きさが変更されるた め, 図 8 における縦軸の数值は記載していない. ここでは, 最小曲線半径として規則で定められる曲線半径 $160 \mathrm{~m}$ の急曲線を想定する．緩和曲線長 $65 \mathrm{~m}$ ，定常円曲線長 $100 \mathrm{~m}$ ，カント量 $65 \mathrm{~mm}$ とし，カントおよび曲率は図 9 のように緩和曲線中で徐々に変化する．また，車輪・レール間の摩擦係数 $\mu$ は 0.4 とする.

また運転規制は自然風速 $w$ の值によって，以下のように走行速度 $v$ が定められている(11).

$$
\begin{array}{lll}
25 \mathrm{~m} / \mathrm{s} \leqq w<30 \mathrm{~m} / \mathrm{s} & : & \text { 徐行 }(25 \mathrm{~km} / \mathrm{h}) \\
30 \mathrm{~m} / \mathrm{s} \leqq w & : & \text { 運転抑止 }
\end{array}
$$

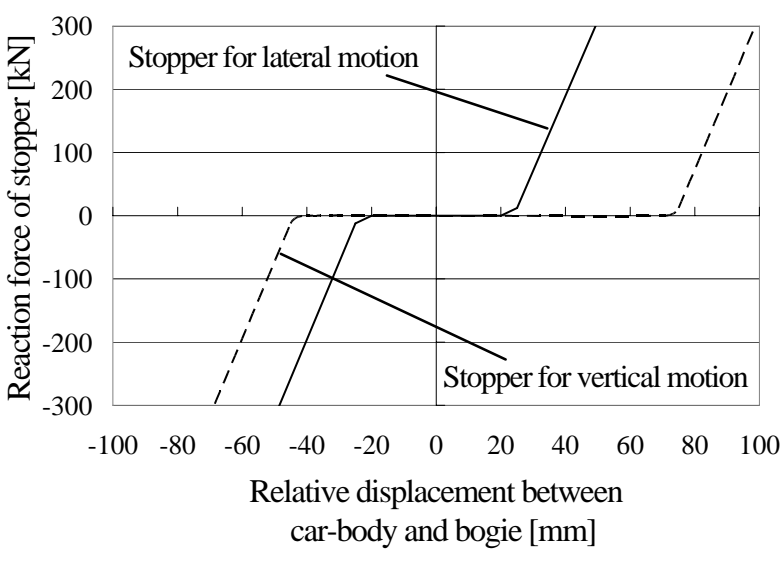

Fig. 7 Reaction force of stopper for relative motion

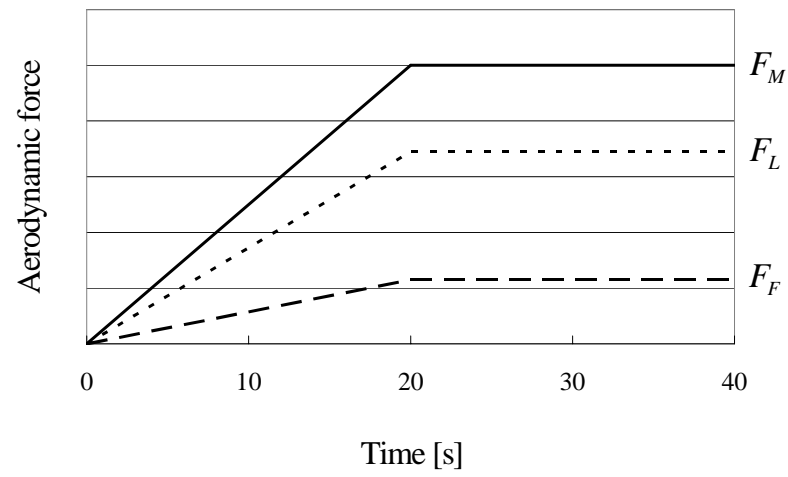

Fig. 8 Input of aerodynamic force 


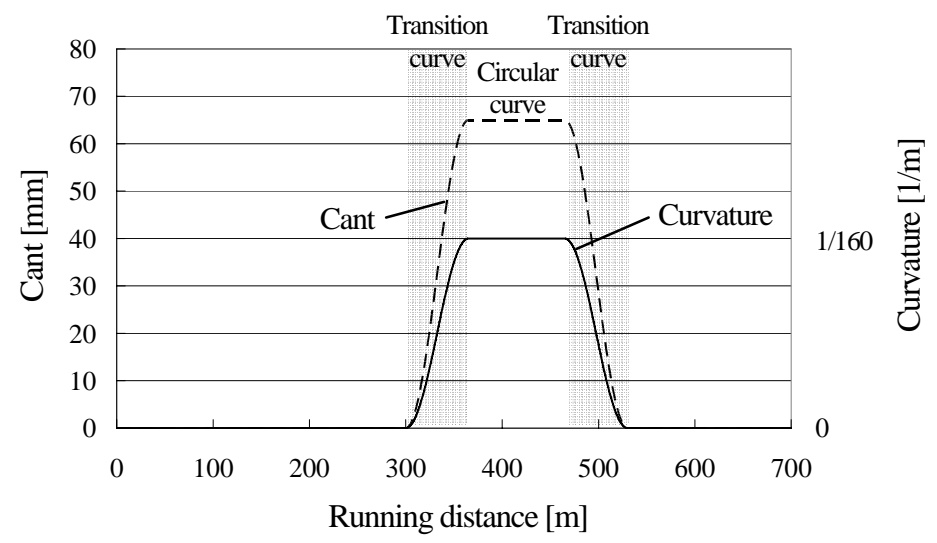

Fig. 9 Running condition

本研究では走行速度はこの曲線での基本速度である $40 \mathrm{~km} / \mathrm{h}$ ，および運転規制速度 $25 \mathrm{~km} / \mathrm{h}$ とする. また車両は空 気力が一定值に達した後，入口緩和曲線に進入し，脱線が最も起こりやすい状況を想定して曲線走行中において も相対風の風向角は $\beta=60^{\circ}$ を維持するものとする.

\section{$4 \cdot 2$ 脱線係数}

脱線発生の可能性を評価する指標として横圧 $Q$ を輪重 $P$ で除した脱線係数 $(Q / P)$ が用いられる. 特に外軌側 脱線係数が大きくなる傾向にある 1 軸および 3 軸に着目して，その両軸の脱線係数の変化を示したものが図 10 である．両軸とも空気力が作用しない場合は定常円曲線中で最大值をとっている．しかし車両に空気力が作用し たとき，脱線係数の值は空気力が作用していないときより増加し，ここで 1 軸は出口緩和曲線中で，3 軸は入口 緩和曲線中でその值が大きくなっている.

脱線の評価指標である Nadal の式による限界脱線係数 $(Q / P)_{N a d a l}{ }^{(9)}$ は式(7)で求められる.

$$
\left(\frac{Q}{P}\right)_{\text {Nadal }}=\frac{\tan \gamma-\mu}{1+\mu \tan \gamma}
$$

ここで， $\gamma$ はフランジ角， $\mu$ は摩擦係数である. 本研究では $\gamma=65^{\circ}, \mu=0.4$ としており, この場合, $(Q / P)_{\text {Nadal }}=0.94$ となる. しかし脱線係数が 0.94 を大きく超えても脱線していない. これは式(7)において脱線に

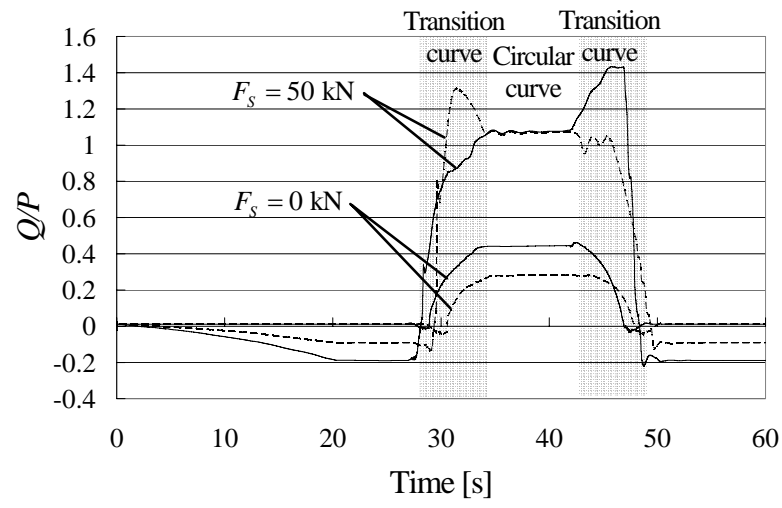

First wheelset --- Third wheelset

Fig. 10 Derailment coefficient of outer wheel $(V=40 \mathrm{~km} / \mathrm{h})$ 
大きく影響を与えるアタック角 $\psi$ が考慮されていないことが一因と考えられる. そこで, 脱線に及ぼす $\psi$ の影響 を考慮するため, 等価摩擦係数 $\mu_{e}^{\left({ }^{(8)}\right.}$ 導入する.

$$
\mu_{e}=\mu \times \frac{\kappa / N \times \psi}{\left\{\mu^{\varepsilon}+(\kappa / N \times \psi)^{\varepsilon}\right\}^{\frac{1}{\varepsilon}}}
$$

ここで， $\kappa$ はクリープ係数， $N$ は垂直力， $\varepsilon$ は飽和特性を表わす指標であり， $\varepsilon=1.5$ としている． $\kappa / N$ は車輪 踏面形状とレール頭頂面形状により求まり，ここでは文献(8)を引用し， $\kappa / N \cong 27.0$ と近似する. このとき，限 界脱線係数は式(7)における $\mu$ を $\mu_{e}$ に置き換え，また輪軸ロール角 $\phi$ を考慮すると次式が得られる.

$$
\left(\frac{Q}{P}\right)_{c r i}=\frac{\tan (\gamma+\phi)-\mu_{e}}{1+\mu_{e} \tan (\gamma+\phi)}
$$

以降，単に限界脱線係数と表記する場合は式(9)を指すものとする.

\section{$4 \cdot 3$ 脱線係数と限界脱線係数の比較}

脱線する場合の例として 1 軸, 3 軸の外軌側脱線係数 $(Q / P)$ と限界脱線係数 $(Q / P)_{c r i}$ のシミュレーション波形 を図 11 に示寸．曲線中においては大きなアタック角が生じるため，等価摩擦係数 $\mu_{e}$ が大きくなり，その結果， 限界脱線係数が小さくなっている. 脱線係数が限界脱線係数に近づくほど脱線しやすくなると考え，ここで情 者の差 $\left\{(Q / P)_{c r i}-(Q / P)\right\}$ が最小になる時刻における $(Q / P)$ と $(Q / P)_{c r i}$ の值を代表値として, 両者の対応関係を 検討する. 脱線する場合には，この時刻近傍において車輪乗り上がりが始まると考えられる.

図 12 は脱線時の自然風速に対寸る脱線係数と限界脱線係数の代表值を示したものである.(a) は $V=25 \mathrm{~km} / \mathrm{h}$, (b)は $V=40 \mathrm{~km} / \mathrm{h}$ の場合であり，図中の四脱線が発生した軸を示している. 脱線が発生した軸に着目すると脱 線係数が限界脱線係数に近い值をとっている. 一方, $(Q / P)$ と $(Q / P)_{\text {cri }}$ の值が接近していても脱線が発生しない 場合も認められる. また脱線発生軸によって代表值や $(Q / P)$ と $(Q / P)_{c r i}$ の大小関係が異なり, 同一の発生軸でも 風速が変化するに従い代表值も変化していく.

また，自然風速を変えながら車両の脱線が発生した位置を示すものが図 13 であり，その位置は縦軸で表され る走行距離によって示される. ここでは運転抑止となる風速 $35 \mathrm{~m} / \mathrm{s}$ 以上で脱線が発生しており, 強風による徐行 速度の $V=25 \mathrm{~km} / \mathrm{h}$ ではより低い風速で脱線することが示される．風速が大きくなるに従い，脱線位置は出口緩 和曲線から定常円曲線，入口緩和曲線へと移動していく，風速がある值以上になると曲線部に進入する前に直線 軌道で転覆が発生している．この傾向は $V=25 \mathrm{~km} / \mathrm{h} ， V=40 \mathrm{~km} / \mathrm{h}$ の場合で同様である．また脱線発生軸は 1 軸

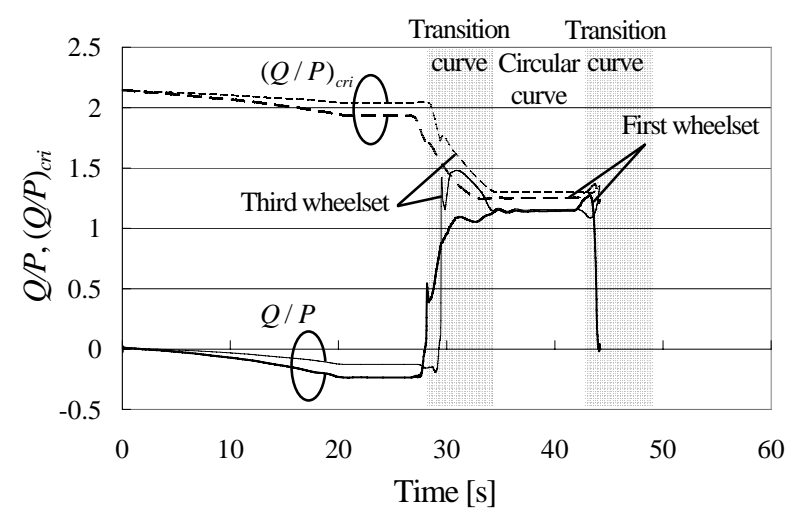

Fig. 11 Example of simulation $(V=40 \mathrm{~km} / \mathrm{h}, w=37.3 \mathrm{~m} / \mathrm{s})$ 


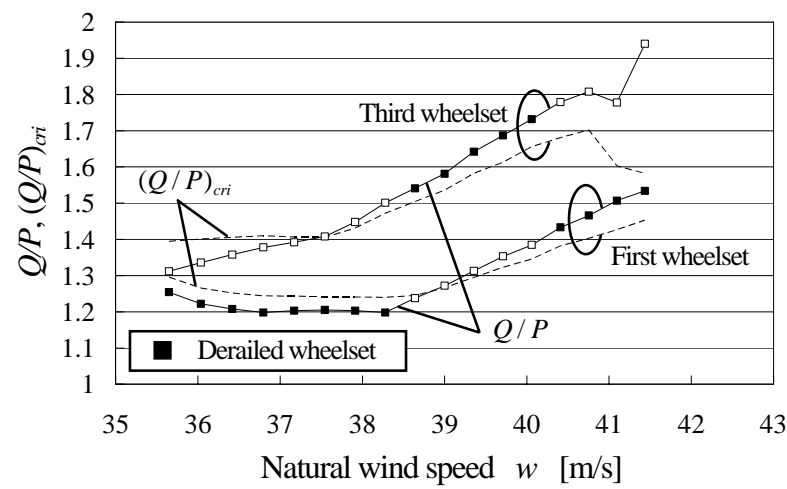

(a) $\quad V=25 \mathrm{~km} / \mathrm{h}$

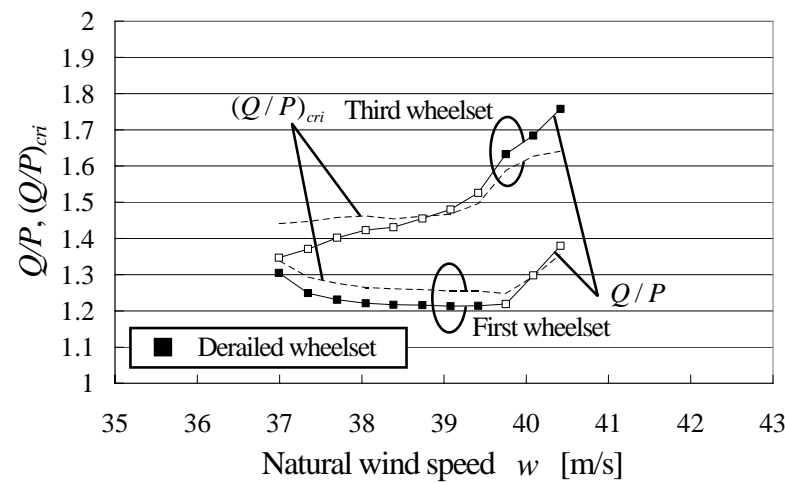

(b) $V=40 \mathrm{~km} / \mathrm{h}$

Fig. 12 Representative value of derailment coefficient and critical derailment coefficient

から始まって 3 軸に移り，さらに風速が大きくなると $V=25 \mathrm{~km} / \mathrm{h}$ においては入口緩和曲線で 1 軸が脱線するこ とが確認される.

図 14 は脱線時の脱線係数 $(Q / P)$ と限界脱線係数 $(Q / P)_{c r i}$ の波形を拡大したものである. 図 $14(\mathrm{a})$ は出口緩和曲 線で 1 軸が脱線する例であり，図 13 における $V=40 \mathrm{~km} / \mathrm{h}, \quad w=37.0 \mathrm{~m} / \mathrm{s}$ の状況に対応するものである. 図 14(a) では $(Q / P)$ と $(Q / P)_{c r i}$ の差は3 軸よりも 1 軸のほうが小さくなっており, そのため 1 軸で脱線が起こる. 図 14(b) は風速が $w=40.1 \mathrm{~m} / \mathrm{s}$ まで増加したとき，入口緩和曲線で 3 軸が脱線する例を示寸． 3 軸の脱線係数は入口緩和 曲線で限界脱線係数に近づき, 3 軸が脱線する.これは 3 軸の $\left\{(Q / P)_{c r i}-(Q / P)\right\}$ が 1 軸のものより早く小さく なるためである.

図 15 は $V=25 \mathrm{~km} / \mathrm{h}, \quad w=40.8 \mathrm{~m} / \mathrm{s}$ の場合における入口緩和曲線での外軌側車輪上下変位と輪軸左右変位の波 形を拡大したものである.1軸の外軌側車輪上下変位がフランジ高さ $30 \mathrm{~mm}$ に達した後, その值は減少しており, そのとき 1 軸の左右変位は単調に増加している。 これは 1 軸が脱線していることを示している．一方， 3 軸の外 軌側車輪上下変位は $30 \mathrm{~mm}$ を超えており，車輪浮き上がりが発生している. これは低速走行により遠心力が小さ くなり，風速の増大によって輪重抜けが起こりや寸くなったことに加えて，入口緩和曲線中のカント増加に対応 して後台車の輪重抜けが発生しやすいためと考えられる.

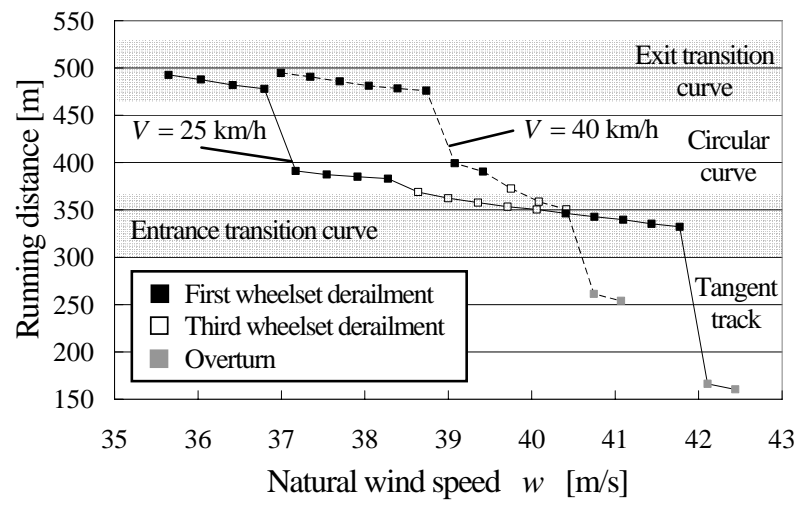

Fig. 13 Position where derailment occurs 


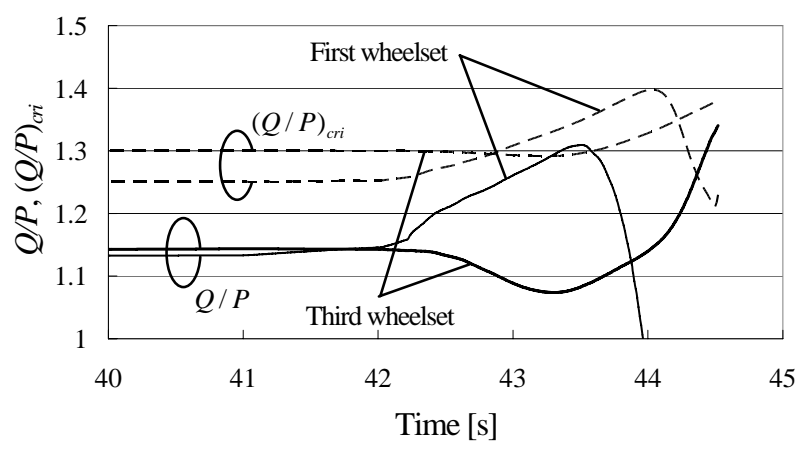

(a) $V=40 \mathrm{~km} / \mathrm{h}, w=37.0 \mathrm{~m} / \mathrm{s}$

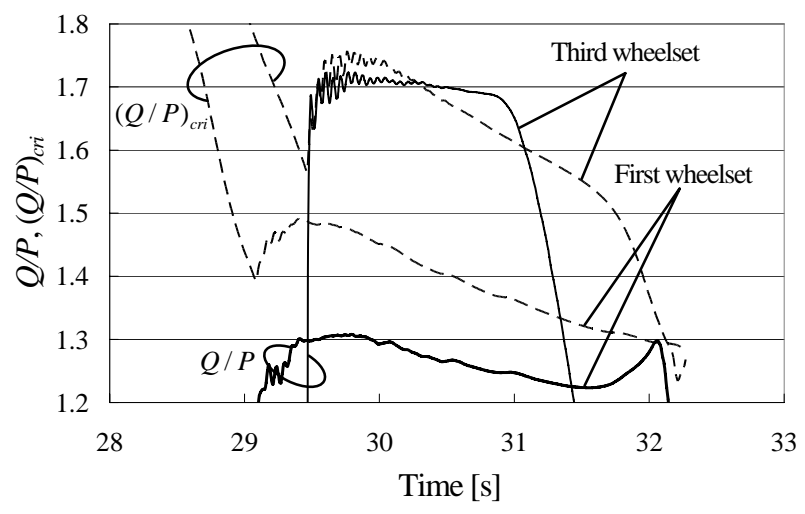

(b) $V=40 \mathrm{~km} / \mathrm{h}, w=40.1 \mathrm{~m} / \mathrm{s}$

Fig. 14 Waveforms of derailment coefficient and critical derailment coefficient
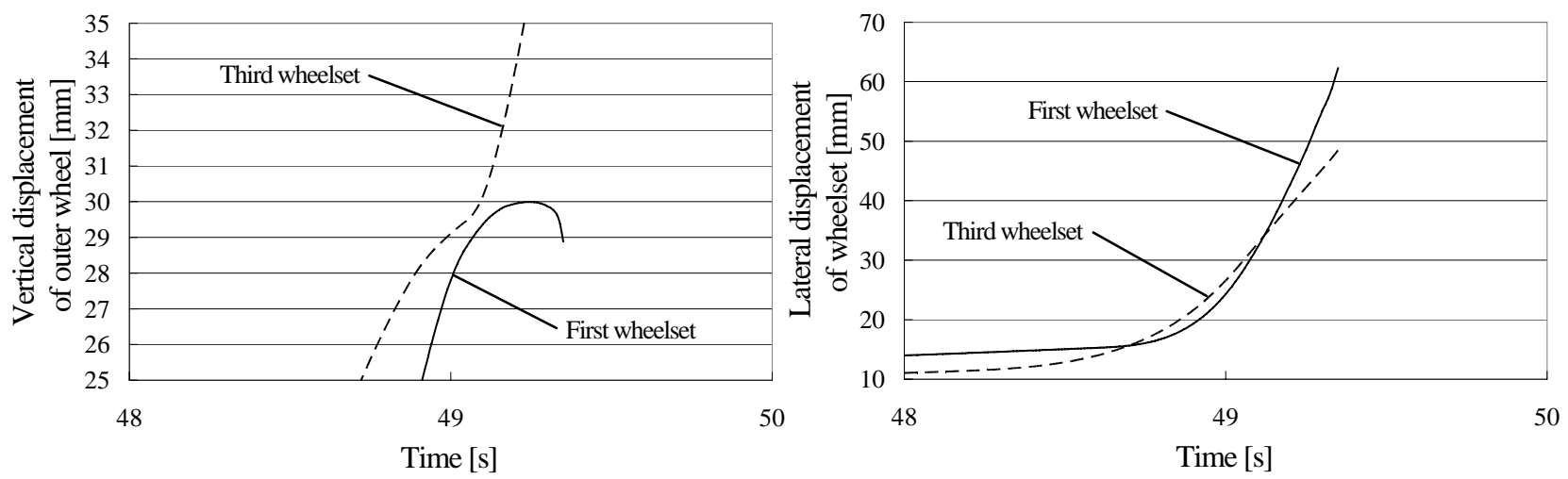

Fig. 15 Simulation results $(V=25 \mathrm{~km} / \mathrm{h}, w=40.8 \mathrm{~m} / \mathrm{s})$

\section{$4 \cdot 4$ 運転規制時の脱線係数と限界脱線係数}

前節では運転抑止風速以上で発生する脱線について検討してきたが，運転規制が実施されるときの脱線係数 $(Q / P)$ と限界脱線係数 $(Q / P)_{c r i}$ についても検討する. ここでは徐行速度 $V=25 \mathrm{~km} / \mathrm{h}$ ，基本速度 $V=40 \mathrm{~km} / \mathrm{h}$ に おいて，運転抑止となる直前の $w=30 \mathrm{~m} / \mathrm{s}$ の横風が車両に作用したときのシミュレーションを行う。各軸におけ る $\left\{(Q / P)_{c r i}-(Q / P)\right\}$ の最小值を示したものが表 1 である. 4.3 節における脱線シミュレーションでは, $\left\{(Q / P)_{c r i}-(Q / P)\right\}$ は 0.05 以下に縮まらなければ脱線は発生しないという結果が得られた. しかし，表 1 の $\left\{(Q / P)_{c r i}-(Q / P)\right\}$ の值はどれも 0.05 を大きく上回っており，運転抑止風速である $w=30 \mathrm{~m} / \mathrm{s}$ の場合でも脱線係 数は限界脱線係数を十分に下回る結果が得られた。

Table 1 Representative values under speed regulation

(a) $V=25 \mathrm{~km} / \mathrm{h}, w=30 \mathrm{~m} / \mathrm{s}$

\begin{tabular}{|c|c|c|c|}
\hline & $Q / P$ & $(Q / P)_{c r i}$ & $(Q / P)_{c r i}-(Q / P)$ \\
\hline First wheelset & 1.18 & 1.35 & $\mathbf{0 . 1 7}$ \\
\hline Third wheelset & 1.08 & 1.39 & $\mathbf{0 . 3 1}$ \\
\hline
\end{tabular}

(b) $V=40 \mathrm{~km} / \mathrm{h}, w=30 \mathrm{~m} / \mathrm{s}$

\begin{tabular}{|c|c|c|c|}
\hline & $Q / P$ & $(Q / P)_{c r i}$ & $(Q / P)_{c r i}-(Q / P)$ \\
\hline First wheelset & 1.16 & 1.37 & $\mathbf{0 . 2 1}$ \\
\hline Third wheelset & 0.90 & 1.39 & $\mathbf{0 . 4 9}$ \\
\hline
\end{tabular}




\section{5. 結 言}

マルチボディソフトSIMPACK を用いて, 急曲線を走行中の車両に外軌側から横風を模擬した外力を作用させ, 走行シミュレーションを実施した．そこでは，Nadal の式に対して等価摩擦係数を用いることにより限界脱線係 数の精度向上を目的として, 脱線係数を用いて車両の脱線挙動を考察した. その結果, 以下のことが確認された.

（1）限界脱線係数の計算に $\kappa$ （クリープ係数） $/ N$ （垂直力）を 27.0 として等価摩擦係数を用いると，脱線が発生 する場合，限界脱線係数は脱線係数と近い值になり，車輪乗り上がり発生の予測に有用である.

（2）風速が徐々に大きくなると，横風による外軌側の輪重減少に加え，前台車に出口緩和曲線中のカント減少に よる輪重減少が加わり，まず出口緩和曲線において 1 軸で脱線が生じる.

（3）さらに風速が増加すると, 後台車に入口緩和曲線中のカント増加による輪重減少が加わり, 脱線の発生箇所 は定常円曲線, 次いで入口緩和曲線に移動し，そこでは 3 軸で脱線が生じる.

（4）徐行速度 $25 \mathrm{~km} / \mathrm{h}$ の速度規制の下では，風速が $30 \mathrm{~m} / \mathrm{s}$ 未満であれば，脱線係数は限界脱線係数を十分に下回 る.

なお，この結果は車両諸元を在来特急電車相当，曲線半径を $160 \mathrm{~m}$, 限界脱線係数の計算において $\kappa / N$ を定数 とした条件のものである. 今回の検討では車輪乗り上がり時の脱線係数と限界脱線係数の值は接近することを確 認できたが，両者の大小関係を論ずるまでには至っていない， $\kappa / N$ も含め，限界脱線係数の精度の更なる向上 が今後の課題である.

付 録

車両に作用する自然風と相対風の関係を以下に示寸.

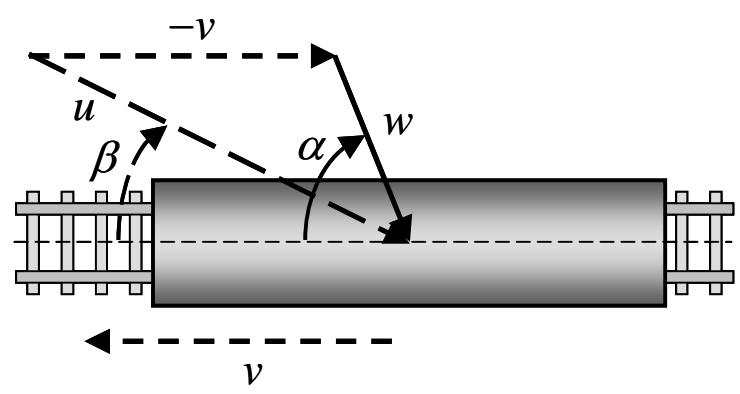

Fig. 16 Wind acting on running vehicle

また計算に用いた代表的な諸元值を以下に示す.

車体質量 : $30.446 \mathrm{t}$

台車枠質量 : $2.45 \mathrm{t}$

車輪軸質量 : $1.6 \mathrm{t}$

車輪平均半径 : $0.425 \mathrm{~m}$

台車輪軸間距離 : $2.3 \mathrm{~m}$

台車中心間距離 : $14.4 \mathrm{~m}$

軸ばね左右間隔 : $1.64 \mathrm{~m}$

空気ばね左右間隔 : $1.93 \mathrm{~m}$

レール面上台車枠重心高さ : $0.50 \mathrm{~m}$

レール面上空気ばね中心高さ : $0.777 \mathrm{~m}$

レール面上車体重心高さ : $1.67 \mathrm{~m}$

車体ローリング慣性半径 : $1.5 \mathrm{~m}$ 


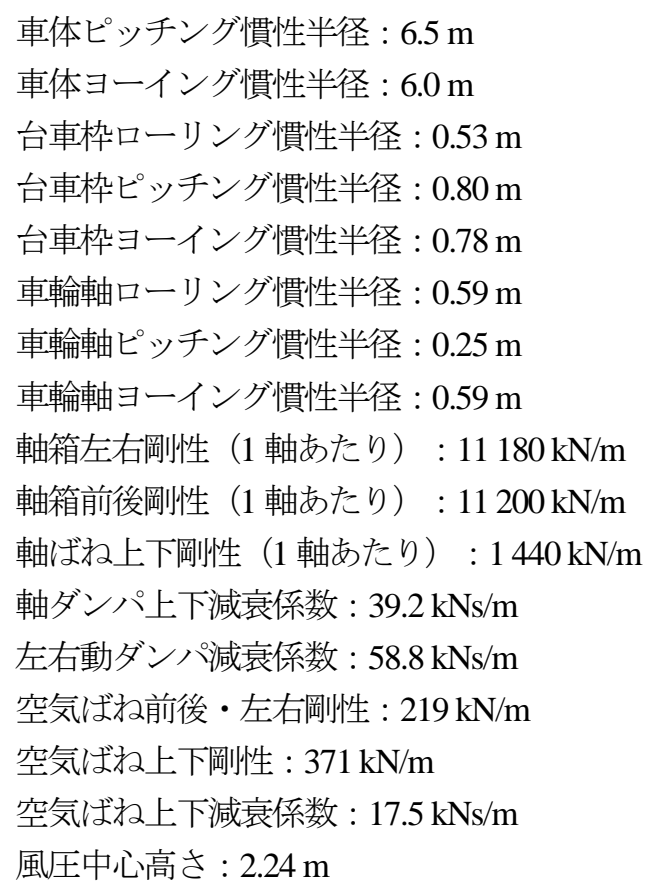

\section{文献}

（1）国枝正春，鉄道車両の転ぷくに関する力学的理論解析，鉄道技術研究報告，No.793 (1972), pp. 1-15.

（2）福地合一，林田千秋，西沢生一，土屋恂，横風による列車転倒の静力学的検討，鉄道技術研究報告，No.854 (1973), pp. 1-42.

（3）日比野有，石田弘明，車両の転覆限界風速に関寸る静的解析法，鉄道総研報告，Vol.17, No.4 (2003), pp. 39-44.

（4）日比野有，下村隆行，谷藤克也，鉄道車両の転覆限界風速に関する静的解析式の検証，日本機械学会論文集 C 編, Vol.75, No.758 (2009), pp. 2605-2612.

（5）航空・鉄道事故調查委員会，東日本旅客鉄道株式会社羽越線砂越駅～北余目駅間列車脱線事故，(2008), pp. 1-98.

（6）島田晃一，谷藤克也，低速で曲線を走行する鉄道車両の走行安全性に及ぼす横風の影響，J-RAIL 2008，(2008-12), pp. 441-444.

(7) Schupp, G., Netter, H., Mauer, L. and Gretzschel, M., Multibody System Simulation of Railway Vehicles with SIMPACK, Vehicle System Dynamics, Supplement to 31 (1999), pp. 101-118.

（8）石田弘明，宮本岳史，前橋栄一，土井久代，飯田浩平，古川敦，急曲線低速走行時の乗り上がり脱線に対する安全 性評価手法，鉄道総研報告，Vol.18, No.8 (2004), pp. 5-10.

(9) Vijay K. Garg and Rao V. Dukkipati, Dynamics of Railway Vehicle Systems, (1984), pp. 76-78, Academic Press.

(10) 文献(5)の p. 70.

(11) 文献(5)の pp. 35-37. 